\title{
Traditions and Rituals of the Naqshbandiyah Order in Pondok Persulukan Darul Aman Purbaganal, Sosopan
}

\author{
Armyn Hasibuan ${ }^{1}$, Muzakkir ${ }^{2}$, Abrar M. Dawud Faza ${ }^{3}$ \\ 1,2,3 Universitas Islam Negeri Sumatera Utara, Indonesia \\ Email:armynhsb@gmail.com
}

\begin{abstract}
This aims of this study is to find out Traditions and Rituals of the Naqshbandiyah Order of Pondok Persulukan Darul Aman Purbaganal, Sosopan. This study use qualitative research design. The result of this study shows that the tradition starts from surrendering oneself to the sheikh or murshid then bathing and dikapi, accepting the tarekat, taking allegiance and others full of traditions and rituals. By staying at Pondok Persulukan, you will be able to follow the traditions, including Suluk customs to completion, genealogy and diplomas. At the Darul Aman Islamic Boarding School, the Ancient Naqsyabandiyah Order, Ganal Sosopan, North Padang Lawas, it was also a tradition to perform ablution, maintain self-purity, perform fardu prayers in congregation during seclusion or not, dhikr, tawajuh, halaqah talaqi, and rabithah.which of course have their own rituals. The results of the tradition at Pondok Persulukan are the adab tradition of respecting the murshid and the tradition of genealogy and diplomas.In relevating the traditions and rituals inherent in the substance of Suluk with Islamic teachings in contemporary life, there are changes found in Pondok Persulukan Darul Aman Naqsyabandiyah North Padang Lawas, especially in traditional and ritual processes. The goal is to accelerate the achievement of increasing understanding and in building personal character and noble character for all tarekat practice students, the existence of linkages in Suluk activities to fulfill religious spiritual needs in society and the existence of the Suluk tradition in the development of non-formal Islamic education.
\end{abstract}

Keywords: tradition; ritual; Naqshbandiyah

\section{Introduction}

Islamic boarding schools are one of the alternative means that can respond to the psychological condition of the elderly, where attention begins to change from worldly material pleasures to efforts to find inner peace and pay more attention to religion as the nature of every human being. $\neg$ Human nature as the essence of himself that does not change throughout time and makes him yearn for the truth whose peak is longing for God. Based on that eternal nature, humans are called upon to accept the true religion wholeheartedly.

The presence of Darul Aman Islamic boarding school, its residents live together, learn while doing charity, strengthen monotheism, seek tazkiyat al nafs tips, are full of spiritual practice, are guided by the sheikh of the tarekat, are full of predictions and wiridan, carry out amali tasawuf as well as contain the meaning of amali and philosophical Sufism, like suluk in Certain days contain philosophical values that practice maqamat as Sufism teachings while anticipating the beginning in each one.

Looking for inner peace, preparing yourself by increasing the provisions of the hereafter before death arrives, for the younger ones it is a cadre of themselves to then open new associations in other places. In Tabagsel (Southern Tapanuli), especially in Paluta, it is known as marpondok. This model is usually led by a murshid of the tarekat or at least a suluk caliph, not just a tawajuh caliph. 
AThere are around 21 places of Pondok Persulukan in Paluta and which have their own uniqueness in the community. In religious discourse, the question is often asked "Madung manarimo ma hamu?" Have you received? Means to accept the "tarekat". There is a view that religion is not perfect when it has not entered or accepted the tarekat, so the tarekat among parents is something high class. Another uniqueness is that it becomes a matter of pride for the elderly community when he is in a lodge, because he is considered to have been able to prioritize the interests of the hereafter and eliminate the worldly.

Marpondokbecome a measure of hagabeon (honorable and noble in social status) as well as a measure of success and success in guiding their children to be able to pay attention, please and bear responsibility in the hut. On the other hand, people are competing to build Islamic boarding schools to provide places for religious learning (fardu ain) and other worship for others, in hopes of doing good deeds and rewarding the sins of existing mistakes. Like Mr. H. Hazairin Siregar, a retiree from Telkom, he owns a plot of land near the GunungtuaSibuhuan highway, approximately 1 ha. Established a religious hut called the Al-Muslimin Aek Haruaya Prayer House and Pondok Persulukan Darul Aman Naqsyabandi Order led by Sheikh H. Muhammad Syukur Mukti Ali Siregar as the place of this research.

The Darul Aman Islamic Boarding School of the Naqsyabandi Purbaganal Sosopan North Padang Lawas was the place of choice for this research which is one of the Naqsyabandiyah institutes of choice for the elderly for activities in cottages, receiving orders and so on carrying out Suluk activities, studying and living, because apart from having a sheikh who remains in the place for the huts is Sheikh H. Muhammad Syukur Mukti Ali Siregar and he is also the chairman of the MUI North Padang Lawas Regency.

For the people of Paluta, the tarekat includes the Islamic boarding school, as a basis for living life and becoming legitimacy in social institutions, idols, value systems and a way out of life's disappointments as the influence of globalization in people's lives. In religion, people view tarekat as a necessity, because only then can one feel how solemn it is to worship and it is with it that one's solemnity is easily achieved.

The reasons for choosing the place of this research include considering input from the supervisor to dip and take root in this research, so that the Islamic boarding school that is studied is only one, namely the Darul Aman Tarekat Naqsyabandi Sosopan Gunungtua Islamic boarding school which is presentative as the object of research by being more open to the outside world, more adapting to the contemporary world. and has a national association, most of the members of his boarding school today, there is never a vacancy of mursyid, his tarekat students often have the advantage of ukhuwah which is still bound by kinship based on customs and religious teachings.

For example, the atmosphere of cohesiveness and togetherness is mainly in the mourning or pilgrimage when someone dies in the area of the Islamic boarding school, they actively give ta'ziah, tahlilan, prayer, recite the Koran together. The influence of the pesantren with its Tsanawiyah and Aliyah students also adds to a livelier and Islamic atmosphere, especially before the pandemic, so that the Islamic boarding school area looks more passionate and has an Islamic nuance.

Because this research will look at the position of traditions and rituals at the Darul Aman Islamic boarding school, it means that this research is generally focused on the internal affairs of the organization, especially the activities and ins and outs of the Suluk rituals in 
which the traditions and rituals will be seen and hacked. In fact, it is necessary to understand suluk correctly.

Based onBased on the background of the problem above, the formulation of the research problem is: What is the position of traditions and rituals at Pondok Persulukan Darul Aman Tarekat Naqsyabandiyah Purbaganal Sosopan Gunungtua North Padang Lawas; and what are the factors of changes that occur in the traditions and rituals.

Then based on the formulation of the problem, the purpose of this study is to find out the description of living Sufism in Islamic boarding schools, then to find out the Islamic concept of living Sufism and Suluk activities at Islamic boarding schools, and also to find out the relevance of living Sufism and Suluk traditions with Islamic teachings in contemporary life. At the Darul Aman hut of the Naqsyabandi Tarekat, Gunungtua, and North Padang Lawas.

\section{Review of Literatures}

North Padang Lawas Regency is one of the regencies originating from the expansion of South Tapanuli Regency which is quite wide from the district in North Sumatra Province. The North Padang Lawas Regency government has been formed since the Law of the Republic of Indonesia Number 37 of 2007 concerning the establishment of North Padang Lawas Regency which was ratified on August 10, 2007 with the administrative capital center being Gunung Tua. Like most other areas in North Sumatra, North Padang Lawas Regency is an area that has a tropical climate and has a hilly topography.

The area of North Padang Lawas Regency is a 'connecting' area between the east coast region which has developed and has become a gateway for national and regional trade with the west coast region which is rich in natural resources and is relatively undeveloped. This position offers advantages and economic opportunities for North Padang Lawas Regency.

Geographically, Padang Lawas Utara is located at $1^{\circ} 13^{\prime} 50^{\prime \prime}-2^{\circ} 2^{\prime} 32^{\prime \prime}$ North Latitude and $99^{\circ} 20^{\prime} 44^{\prime \prime}-100^{\circ} 19^{\prime} 10^{\prime \prime}$ East Longitude.

Based on Law no. 37 of 2007, the administrative area of North Padang Lawas Regency covers 9 sub-districts, namely: Batang Onang District, Dolok District, Dolok Sigumpulon District, Halongonan District, Hulu Sihapas District, Padang Bolak Julu District, Padang Bolak District, Portibi District, Simangambat District and has 386 village and 2 wards.

\section{Research Methods}

This type of research is a qualitative research using a Sufism approach, then enriched with a socio-cultural approach based on the study of traditions and rituals which are described based on data about traditions, rituals and other things.Holistically described in the form of words, statements and sentences in natural and scientific contexts that utilize various scientific methods. 


\section{Discussion}

\subsection{The Position of Traditions and Rituals Practiced at the Darul Aman Islamic School of the Naqsyabandiyah Order of Purbaganal Sosopan Gunung Tua}

Broadly speaking, there are 4 (four) concepts of tradition at the Darul Aman Naqsyabandiyah Tarekat Islamic boarding school, namely entering the tarekat, accepting the tarekat, the tarekat routine and completing or khataman as a result of the Tarekat form. Rituals are attached to every tradition, so that between traditions and rituals are two different substances but go hand in hand in cultural, religious, and customary life with their respective domains and components that have been standardized.

\subsection{The Tradition of Entering the Pondok Persulukan a. Bath Ritual}

A person who wants to become a student at the Darul Aman Congregational Islamic Boarding School, the Naqsyabandi Order, must first follow the various traditions and rituals that are carried out in the Islamic boarding school. Among the traditions and rituals is being told to take a bath, according to the sheikh is a bath of repentance. Bathing is usually done at night. At the Darul Aman Persulukan Pondok this midnight at 24.00 WIB. with a series of murshid's guidance. He was ordered to use an even intention and use a kaffir lime that he cut into the water in a basin, then he made an incantation (prayer) and then it was given to people who want to accept the tarekat to be bathed. This is the traditional ritual of bathing and dikapi which is carried out by Darul Aman Persulukan Pondok as part of the procedure for entering the Persulukan Pondok.

All members of the Islamic boarding school cannot be separated from the tradition of entering the tarekat that has been passed down from generation to generation with the legitimacy of the Sheikh or other murshid. In the study of the ritual, bathing is meant as a bath of repentance, has a certain time, the goal is to be clean from sin and is loyalty to the teacher. It has a plot structure by preparing various ingredients and ingredients such as kaffir lime which contains various benefits, including the aroma on the skin, which stimulates people to be more relaxed and relaxed. Even kaffir lime boosts the body's immune system with vitamin C, so that the body's strength is not in doubt even though it is in the process of receiving the tarekat take until dawn.

\section{b. Ritual of Dikapi}

After the prospective students take a bath according to the direction of the sheikh, take wuduk and then are told to pray repentance and prayer circumcision intent. Then he will be treated like someone who has died, and the place of acceptance of the tarekat (usually the shared tawajuh room) is where the prospective student is laid with the guidance of the remembrance of the sheikh until he falls asleep before dawn. In kafani, this also refers to the implementation of the tarekat from his parents from generation to generation and changes in certain things as a reform formulation according to Sheikh H. Muhammad Syukur Mukti Ali Siregar.

In this activity, Sheikh H. Muhammad was grateful that Mukti Ali Siregar had allowed him to be replaced, with the ability of prospective students to cry when they feel reluctant to be met, usually they are people who are still relatively young. For Sheikh H. Muhammad, thanks Mukti Ali Siregar, the shroud ceremony is an afterthought and at one time anyone will experience the same thing, whether young or old. The cry that replaces the arrest is proof of the sincerity and consideration of prospective students to enter the tarekat. This means that he has strong aspirations and is even willing to be witnessed by the mursyid.

Finally, Sheikh H. Muhammad thanks Mukti Ali Siregar concluded it as the seriousness of his prospective student by shedding tears, living the muhasabah and contemplating from all aspects when the process of dying to the grave, so that it can be accepted instead of being caught. 
A murshid will peek at the student from his ma'rifah and he knows for himself the moment when the prospective student is complacent or sleepy which causes his body position to be reversed and then conscious. That's when the murshid mentally qin into the ears of prospective students something that is usually a secret between the sheikh and him. According to Syekh H. Mukti Ali Siregar, a slight mental qinkan incident is what is called accepting the tarekat, not being bathed or held. although all of them become a series of ties of receiving tradition.

After dawn, if there is still time, the Shaykh will ask his prospective students about what happened last night through dreams or worries. The sheikh as the murshid will provide sufficient explanation and he knows whether the prospective student really carries out his directions and even knows the grace or deception of Satan who has come to the prospective student.

From the process of taking a bath to the time of the bathing process, the writer can position that bathing is a tradition, even humans, where and whenever they will bathe, but on the other hand, they collaborate with rituals with the component component of the perpetrator, including the Sheikh and prospective students. midnight. Its function is as a tradition and ritual that has been running sacred all this time, from generation to generation, the place for the ritual itself, using the regional/customary language and religion and the action is carried out in action and directly with the intention and prayer of the sheikh's guidance. What is interesting is that the domain of tradition is collaborated with rituals.

This activity is a ritual that is strongly believed to be an exterminator or antidote to satan, to use other people and is a waste of sin because it is accompanied by the intention of repentance because of Allah Ta'ala and also increases the body's immunity according to modern scientific explanations that in kaffir lime there are substances that can relieve stress, increase immunity. body, eliminating bad breath, reducing inflammation of rheumatism and joints, repelling insects, especially mosquitoes, which have a very negative impact on those who are accepting the tarekat, which will be followed by the bai'at ceremony and so on.

\subsection{The Tradition of Receiving the Order}

The habit of accepting the tarekat prospective students to state their intentions and intentions while submitting themselves to be guided by the murshid or sheikh directly. Then the sheikh provides guidance and instructions from the murshid or sheikh. The guidance is in the form of etiquette that must be carried out by students in undergoing Suluk at Darul Aman Persulukan Pondok and also as a practitioner of the tarekat.

\section{a. The ritual of allegiance}

Bai'atmeans pledging allegiance, confirmation, appointment, official inauguration or taking an oath of allegiance to a leader. In the next sense bai'at or bai'ah is a pledge or rite of ordination to enter into a Sufi order. That pledge is actually a pledge between Allah SWT. and His servants. Always bind the murshid and the student together. Within the bai'ah, there is a sacred moment when spiritual energy (barakah) in the spiritual chain (silsilah) is transferred from the murshid to the pupil. It enables the murshid to travel safely and safely under divine protection and with divine help as well.

\section{b. Adab in the Ritual of Bait}

The procession of this activity is carried out together with other students in a certain room, usually at the mosque after the talk is complete.For a tarekat student, there are many adab that must be carried out in achieving the perfection of the tarekat itself.

The etiquette includes:

a) Filling free time with remembrance to keep the heart from turning gray 
b) Getting used to berkhatam at the time of Asr and Fajr and Isha is a ritual event at certain times the students gather with the caliphs in a place designated for dhikr and pray together led by a murshid or sheikh.

c) Maintaining something or the grace obtained (in the form of muraqabah)

d) Increase the deeds of worship and stay away from all kinds of immorality.

e) Avoid arguing with people who denounce mysticism.

f) Inviting others to enter the congregation of associations to increase goodness.

g) Behave like people who do mysticism that is sporty and full of practice and wiridan.

h) Always be with the teacher for guidance.

i) Believing that the teacher is the caliph, namely the substitute for the apostle in the world, even though he is relatively young, it is the teacher who provides him with inner and outer provisions.

j) Wake up every night at 3 in the morning to perform the tahjjud prayer.

k) Avoid smoking and eating meat.

l) It is not allowed to inform the remembrance that is read to other than the caliph.

The above etiquette seems to violate human customs, such as being prohibited from eating meat during Suluk activities as well as smoking. It turns out that after researching there isbenefit This is because people who consume meat, protein and other nutritious foods will overheat the body and even increase their lust or sexual power. Likewise smoking will disturb himself busy and inhaled smoke, then he too will not concentrate in remembrance and other acts of worship.

\subsection{Traditions in the Implementation of Tarekat Routines a. The Ritual of Settling in the Pondok Persulukan}

A hut is a residence in an Islamic boarding school or mukim for an unspecified time, carried out by the elderly in North Padang Lawas Regency to get closer to God and reduce the love for the luxury of the world which often implies restlessness and educate themselves better equipped with the hereafter by carrying out fardu ain and other things circumcision. In the local language, the word pondok with emphasis on the sound is called "dok", which can be interpreted as 'short' versus long. The meaning of huts can also be interpreted to shorten the soul from a life that neglects itself from Allah SWT. by departing to stay in isolation and then forming a community that shares the same understanding and outlook on life to get closer to Allah swt with repentance nasuha.

The Darul Aman Islamic School of the Naqsyabandiyah Order where the community of tarekat practicers live, most of them study the tarekat, inner deeds and heart work so that they are good at getting closer and submitting them to Allah SWT. maintaining worship and some of them still aspire to develop it in other places as part of Islamic da'wah. It is to pursue and learn this knowledge that most students come to study. They come from various areas in the North Padang Lawas region and also from various areas in Southern Tapanuli.

In order to be more solemn and more focused, they have to live and settle in the cottage so that if it is likened to the cottage today, it is a dormitory for students in modern Islamic boarding schools. It's just that this lodge is different from the physical dormitory building. Lodging is more flexible and independent because many of the students are people who are between the ages of 50-70. If seen and traced, it becomes a belief of the elderly (elderly) people in North Padang Lawas if they have reached the age of 50 years and over, have no dependents and have a good economy, they should immediately enter the Islamic boarding school.

Students who are still relatively middle-aged, usually don't stay too long in Pondok, they are more likely to acquire knowledge within a few years to pursue a diploma and can be appointed as caliphand will take part in other places such as opening a new organization. According to the history narrated by Sutan Guru Hasibuan that the origin of this marpondok in the North Padang 
Lawas area was a Suluk activity in 1925 at the Daru Salam Poken Salasa Islamic boarding school, Portibi District now, after the seclusion activity was over, the place was also used as a mukim residence and that's how it developed. become a lodge that is not only used during mysticism seasonallybut became a continuous tradition.

The researcher ventured to say that when a hut is a tradition, the ritual is an exerciseseclusionbecause he was born alone and will return to Allah alone, then kun ma'a Allah wa inlan takun ma'a Allah Fa takun ma'a man ma'a Allah is the content and essence of the lodge itself. The practice of seclusion is meant to train oneself to be lonely in a crowd and crowded in loneliness. Thus, their lives in the huts of association continuously are like Sufis who are zuhud, patient, mujahadah bi amal, qanaah, istikomah and simple appearance, are like zahid and their sincerity in treading the paths of the tarekat to the path of Allah swt.

\section{b. Rituals to maintain self-purity}

Sufism or tarekat is having character with Allah's character so that the most holy God is pleased with His servants who are in cleanliness and holiness because He Himself is most holy and happy with clean people. In the Darul Aman Islamic boarding school community, it is customary to make wuduk water for all Suluk participants, by repeating the wuduk every time it is canceled, even before it has been canceled, it has been updated with a newer wuduk to make it more enthusiastic and eliminate drowsiness.

With a wet face and a sweep of the crown of the head, it will provide relaxation to the sensory center, namely the brain with awakening reflexes and a sense of satisfaction accompanied by calm.It will be very different from people who are always in the heat of the day or emotional overflow is shocked by a heartbeat caused by worry and anxiety. So with water ablution that is framed with the belief that every command of God and His Messenger contains in it goodness and secrets that often cannot be clearly revealed.

Wuduk with remembrance continues to be paralleled incottage life. Through this remembrance, according to Muzakkir, it will shape oneself, renew attitudes, increase the potential for nature in understanding Allah's creation as a manifestation of the essence of seeking identity. In addition to establishing yourself, it is also a way to increase energy to do goodand avoiding negative things, and this is a form of mental therapy that is carried out in the huts of persulukan. However, to carry out this remembrance in its application at Darul Aman Islamic Boarding School is to maintain physical cleanliness by performing ablution. While this remembrance is a therapy to fill the void of the soul of a disciple who has been takhalli and is a maintenance of inner cleanliness.

\section{c. Congregational Worship Rituals}

Congregational prayer is basically a ritual and many texts show its existence as a teaching of the Islamic religion. What has become a tradition is to get used to the congregation by strengthening doctrine and the tradition to focus on the obligatory prayers five times a day and night. As for the muakkad circumcision prayers, such as qabliyah and ba'diyah circumcision, tahajjud and other nawafil prayers, they are performed in a munfarid manner, even in their respective huts. This has become a customary tradition that is carried out by members of the cottage both outside the time of Suluk, especially during Suluk. The salik were awakened and accustomed to evening prayers and various daily circumcision prayers. This habit of praying in congregation has become a necessity for the salik at Darul Aman Persulukan Pondok. 


\section{d. Dhikr Ritual}

Remembrance is a series of rituals and things that are central to survival in a hut of worship, starting from a mild level to a high level of complexity, no breath without remembrance, no movement without remembrance, all conditions of remembrance of Allah SWT. According to the results of an interview with a mother that the phrase Lailaha illa Allah is the basis and can dispel the confusion of the mind and the restlessness of the soul by engrossing it with sound and motion. Regarding the sound and motion in doing tahlil, it is a tradition that begins with a low voice and then gets stronger, accompanied by stronger movements. Along with putting a sentence to his station and concentrating himself, Sheikh Fadhlalla Haeri said that there is no doubt that the remembrance of Allah's name is very helpful in achieving serenity and inner peace.

Basically remembrance is a wordmusytarakhas a double meaning, namely mentioning and remembering, saying there are certainly sounds, sentences and letters while remembering is psychic work without letters, words and sounds. Both are used in Darul Aman Persulukan Pondok. People who do dhikr are people who fill themselves, self-seeking, namely understanding the nature of humanity that can be realized in morality and spirituality. The self which consists of the spiritual can contain the divine and the physical aspects are required to do charity. Both need to be directed and confronted by Allah SWT. place of return. Haidar Bagir to Nurcholis Madjid said that the human heart as the house of Allah SWT in humans, needs to be emptied of the despicable nature of humanity so that Allah SWT. can reside there. With the remembrance of La ilaha illa Allah, that is one that can empty or clean the heart of everything that pollutes it. The blow and the power of the blow that is moved towards the heart will be able to return the heart to a clean, clear and holy atmosphere.

Presenting God within should not be understood literallymujassima(understanding that Allah SWT consists of physical and character) or imagining that an official can be invited and then come to the room held by the committee, but by faith it is explained "...Whoever remembers Me in himself, I remember him in My essence ..."Sufis and saliks are no exception at the Darul Aman Islamic boarding school, the Naqsyabandiyah congregation believes that suluk is a way of filling oneself which is applied with practice and remembrance itself, murshid as mentors, students as learners, while the material for this is practice. kullu bodies that refract the physical members with various stations at the same time domiciled as a ritual.

\section{e. Tawajuh Ritual}

Tawajubmeans facing Allah swt. with a series of ceremonial remembrance together led by the sheikh or at least the caliph of tawajuh or the caliph of the tarekat, this they do when there is suluk activity or not during suluk. In plain view, the implementation ceremony contains standard rules, although there are small differences from one college to another. It is stated in the table that tawajuh is in the form of a congregational remembrance of remembrance between teacher and student and student and other student, because in practice the sheikh begins to lead it by saying istighfar three times and the fourth time is followed by all students together by lengthening the end of the sentence in a silent tone.

One of the caliphs who sits on the right of the sheikh reads the word of Allah in QS Al Taubah/9: 128-129:

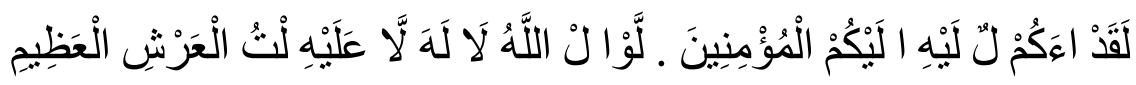

"Indeed, there has come to you an Apostle from your own people, your suffering is heavy with him, eager for (faith and salvation) for you, very merciful and merciful to the believers. if they turn away (from faith), Then Say: "Allah is sufficient for me; there is no god but Him. Only in Him do I put my trust and He is the Lord who has the 'Great Throne." 
Then there are 30 pebbles divided by rolling 15 seeds to the student to the right of the sheikh and another 15 to the student to the left of the sheikh.The gravel will eventually return to the sheikh, then one of the caliphs says:

1) Sholawat al Syarifah!

2) Ikblasu al Syarifah!

3) Alamnassyrahi al Syarifab!

4) Then all of them read the Prophet's Salawat, Surah Al Ikhlas and Surah Al Syarh, each 7 (seven) times.

After that, then read istighfar by lengthening the tone at the end of the sentence and for a while while contemplating and regretting sins whileking'hoping for forgiveness and guidance from Allah swt. The sheikh can see which of his students has reached the level of the caliphate and bestows his knowledge ma'rifah on certain and worthy students. According to him, sometimes the murshid touches his knee to the knee of his favorite student or his forehead to the forehead of his student as a sign to bestow scientific knowledge while hoping to Allah SWT. so that the disciple gets a gift or mercy from Him. Doing this gesture can be represented by the sheikh to the caliph and the sharifah for the women.

After that the sheikh gave a sign that the tawajuh would soon be ready, only a caliph read the word of Allah SW'T QS al-Fajr / 89: 27-30 reads:

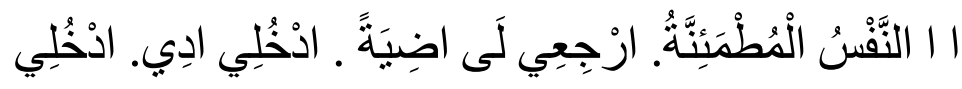

'O calm soul. Return to your Lord with a contented heart and pleasing to Him. So enter into the congregation of my servants, Enter into My paradise. '

Ceremoniously,tawajuhhas finished and the shaykh ordered the students to continue dhikr in their respective mosquito nets at the time of suluk. However, if you are not doing suluk then it is permissible to disband because it has been completed. This is what was carried out at the Darul Aman Naqsyabandiyah Purba Ganal Sosopan Gunungtua Paluta Islamic boarding school, which had a tradition of being accepted by Sheikh H. Muhammad Syukur Mukti Ali Siregar from his father and his father also receiving it from his teacher.

\section{f. Halaqah Talaqi Ritual}

Learning activities through mustami' (listening) in living Sufism at the Darul Aman Tarekat Naqsyabandiyah Islamic boarding school is an important and continuous activity because apart from waiting for the time for the Isha prayer to arrive, especially those who do not have the need for religious education, they can ask Ustadz either the caliph or sheikh or other teachers. This activity is mainly outside the Suluk time, they are often guided by the caliph Sarmadhan Siregar with relatively various kinds of books.

Caliph Sarmadhan Siregar besides being an active resident of the lodge, the longest studying at the Darul Aman Naqsyabandiyah Islamic boarding school was since the parents of Sheikh H. Muhammad Syukur Mukti Ali Siregar, Tuan Guru Muhammad Jamil Siregar, were still alive, he also had a scientific basis that was more than adequate for a Tawajuh caliphs and tarekat caliphs are also known as Suluk caliphs. He graduated from the seventh grade of Tsanawiyah and Aliyah at one of the Islamic boarding schools in North Padang Lawas in 1978. He is also a caliph who is favored by Sheikh H. Muhammad Syukur Mukti Ali Siregar because he is responsible and has a simple and humble personality, especially with the same clan. Siregar. 


\subsection{Ritual Rabithah}

In the practice of the Naqshbandiyah order, rabithah is a tradition that is indoctrinated by the sheikh and passed down from generation to generation from time to time until now wherever it is carried out and at the same time contains rituals. In essence, it is a spiritual bond of friendship between the student and the murshid who is in a knot of friendship guided by the direction of a sheikh. Friendship is a friendship that begins with seeking the pleasure of Allah, loving each other in the name of Allah and parting (when death comes) parting in the holy sentence of remembrance of Allah swt. according to the sheikh's guidance so far.

\section{Conclusion}

Traditions and rituals have an important position to be recognized as two imperfect parallel runs without the other side as sacred images of actions that remind primordial events while preserving and transmitting them to society, actors are seen as equal to the sacred past and perpetuate the sacred tradition and renew the functions of life. members or followers. Tradition is embedded in the culture of an ethnicity, in which a religious teaching becomes a religious tradition containing rituals such as the substance of Suluk comprehensively.

Darul Aman is the name of one of the organizations that is the object of this research, where a student who will enter and participate in all the activities of the Islamic boarding school must follow the traditions and rituals that exist in this Islamic boarding school.

The tradition starts from surrendering oneself to the sheikh or murshid then bathing and dikapi, accepting the tarekat, taking allegiance and others full of traditions and rituals. By staying at Pondok Persulukan, you will be able to follow the traditions, including Suluk customs to completion, genealogy and diplomas. At the Darul Aman Islamic Boarding School, the Ancient Naqsyabandiyah Order, Ganal Sosopan, North Padang Lawas, it was also a tradition to perform ablution, maintain self-purity, perform fardu prayers in congregation during seclusion or not, dhikr, tawajuh, halaqah talaqi, and rabithah.which of course have their own rituals. The results of the tradition at Pondok Persulukan are the adab tradition of respecting the murshid and the tradition of genealogy and diplomas.

In relevating the traditions and rituals inherent in the substance of Suluk with Islamic teachings in contemporary life, there are changes found in Pondok Persulukan Darul Aman Naqsyabandiyah North Padang Lawas, especially in traditional and ritual processes. The goal is to accelerate the achievement of increasing understanding and in building personal character and noble character for all tarekat practice students, the existence of linkages in Suluk activities to fulfill religious spiritual needs in society and the existence of the Suluk tradition in the development of non-formal Islamic education.

\section{References}

Akbarizan.Tasawuf Integratif Pemikiran dan Ajaran Tasawuf di Indonesia. Pekanbaru: Suska Press, 2008.

Al-Bamar, Khalili, dan I Hanafi R. Ajaran Tarekat: Suatu Jalan Pendekatan Diri Terhadap Allah Swt. Surabaya: Bintang Remaja, 1990.

Al-Ghazali, Imam.Khulashah al- Tashanif fi al-Tashawwuf. Beirut: Dar al-Kutub al-Ilmiyyah, 1994.

Al-Kurdi, Muhammad Amin.Tanwir al-Qulub. Bairut: Darul Fikr, 2009.

Al-Naqshabandi, Ahmad Musthafa.Jami’ al-Ushul fi Al-Awliya. Kairo: Dar Al Kutubal Arabiyah, 1910. 
Kāshān̄̄, 'Abd al-Razzāq al-.Ishthilahat al-Sufiyah. Mesir: al-Hay’ah al-Mishriyyah al-Ammah li al-Kitab, 1981.

Mulyati, Sri. Mengenal \& Memahami Tarekat-Tarekat Muktabarah di Indonesia. Jakarta: Kencana Prenada Media Group, 2011.

Muzakkir, H. "Relevansi Ajaran Tasawuf Pada Masa Modern.”MIQOT: Jurnal Ilmu-Ilmu Keislaman Vol. 35, no. 1 (2011): 37-58.

"Tasawuf dalam Kehidupan Kontemporari: Perjalanan Neo-Sufisme." Jurnal Ushuluddin Vol. 26, no. 1 (2007):

. Tasawuf dan Kesehatan Psikoterapi dan Obat Penyakit Hati. Jakarta: Prenada Media Group (Divisi Siraja), 2018.

Tasawuf: Pemikiran, Ajaran dan Relevansinya dalam Kehidupan. Medan: Perdana Publishing, 2018.

Said, Ahmad Fuad.Hakikat Tarikat Naqsyabandiah. Jakarta: Pustaka Alhusna, 1996.

—. Syekh Abdul Wahab, Tuan Guru Babussalam. Medan: Pustaka Babussalam, 1983.

Simuh.Tasawuf dan Perkembangannya dalam Islam. Jakarta: Raja Grafindo Persada, 1999.

Smith, Margareth. Al-Ghazali The Mistic Edisi Indonesia Pemikiran dan Doktrin Mistis Imam Al-Ghazali. Diterjemahkan oleh Amroeni Drajat. Jakarta: Riora Cipta, 2000.

Trimingham, J. Spencer. The Sufi Orders in Islam. Walton Street Inggris: Oxford University Press, 1998.

Van Bruinessen, Martin. Kitab Kuning Pesantren dan Tarekat: Tradisi-Tradisi Islam di Indonesia. Diterjemahkan oleh Farid Wajidi dan Rika Iffati. Bandung: Mizan, 1995.

Yusuf, S. Maryam. "Inter-Subjectivity of Khalwat (suluk) Members in the Tarekat Naqsyabandiyah Khalidiyah Ponorogo.'Indonesian Journal of Islam and Muslim Societies 10, no. 1 (2020) 